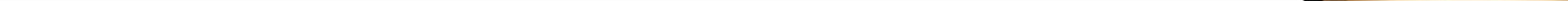




\section{The Special Issue Editors}

Veronika Bernard (PhD) is an Associate Professor (Privatdozentin) with the Department of German language and literature at the University of Innsbruck and a member of the research platform CenT (Cultural Encounters and Transfer). She is one of the two directors of the IMAGES project (conferences, publications, exhibitions, online contests; www.images-1.over-blog.org) and has been the director of the project "Breaking the Stereotype. Oriental and Occidental Stereotypes in the Course of Time" (www.breaking-the-stereotype2009-2010.overblog.org). Veronika Bernard is a member of the advisory board of CINEJ, the international refereed online cinema journal published by the University of Pittsburgh (http://cinej.pitt.edu).

She has earned her postdoctoral qualification (Habilitation) in German literature. Her doctoral thesis is on the Orient in $19^{\text {th }}$ century Austrian travel writings.

Her research interests are: cultural encounters in movies; migrant literature (German-Turkish authors); European views and stereotyping of the Orient; the city in literature.

She is the editor (together with Serhan Oksay and Eugene Sensenig-Dabbous) of the book "Breaking the Stereotype. From Orient and Occident to a Mutual Understanding of Images" (Innsbruck: iup 2011). For further publications see www.v-b-publikationen.over-blog.de.

e-mail: veronika.bernard@uibk.ac.at

Serhan Oksay (PhD) is an Associate Professor and chair of the Department of Business Administration at the Kadir Has University, Istanbul and coordinator of the MBA program.

$\mathrm{He}$ is one of the two directors of the IMAGES project (conferences, publications, exhibitions, online contests; www.images-1.over-blog.org) and has been the leader of the creative team of the project "Breaking the Stereotype. Oriental and Occidental Stereotypes in the Course of Time" (www.breaking-the-stereotype20092010.over-blog.org). Serhan Oksay is one of the founders and a member of the advisory board of CINEJ, the international refereed online cinema journal published by the University of Pittsburgh (http://cinej.pitt.edu).

His research interests are: international political economy, sustainable development and poverty, environmental problems and politics.

$\mathrm{He}$ is the author and editor of several publications, among them the book "Breaking the Stereotype. From Orient and Occident to a Mutual Understanding of Images” (Innsbruck: iup 2011).

e-mail: serhano@khas.edu.tr; serhano@serhanoksay.com 
Vedat Akman (PHD) is a faculty member at Beykent University. He has been teaching at Kadir Has University, worked as a research manager in major Turkish banks and stock-exchange companies in Istanbul. He produced TV business programs and wrote columns in national newspapers.

Vedat Akman is actively involved in the Cross-Cultural Dialogue Platform in association with Turkish Grand National Assembly and Department of National Monuments and Museums. He is the founder of JCI Istanbul Crossroads (www.jcistanbulcrossroads.com), an immigration themed international short film festival, and one of the founders of CINEJ, the international refereed online cinema journal published by the University of Pittsburgh (http://cinej.pitt.edu).

He edited GLOBAL IMMIGRANT STORIES, a collection of immigration related information and real life stories written by immigrants and received the "Best Publication in Europe" award at the JCI European Area Conference in Maastricht in 2007.

For further information on his work please visit www.vedatakman.com.

e-mail: akmanvedat@yahoo.com

Murat Akser (PHD) is an Assistant Professor of cinema and media studies at the Department of Radio, Television and Cinema at Kadir Has University, Istanbul/ Turkey and director of the Cinema and Television program. He has his MA in Film and his PhD in Communication and Culture from York University, Toronto/ Canada. Akser works extensively on political economy of the media and surveillance. He published a book length study of Turkish cinema titled Green Pine Resurrected with Lambert Academic Publishing in 2010.

$\mathrm{He}$ is one of the editors of CINEJ, the international refereed online cinema journal published by the University of Pittsburgh (http://cinej.pitt.edu).

e-mail: makser@khas.edu.tr 